\title{
The Bologna Process as a New Public Management Tool in Higher Education
}

\author{
Stanislav Štech
}

Abstract: This essentially polemical article questions whether the Bologna Process (BP) is necessary (and desirable) in the adaptation of universities to the new social conditions or whether it is a Trojan horse sent out to introduce neo-liberal changes in the field of higher education. First, it addresses the circumstances surrounding the origins of the Bologna Declaration, demonstrating that it enabled the instrumental logic of the marketization and commodification of education to pervade universities traditionally conceived of as cultural institutions of knowledge. It then investigates the eight declared objectives of Bologna and, finally, summarises the consequences that can be firmly established ten years after the event. These include the fact that three of the pillars of the BP can be interpreted as responding to the requirements of neoliberal New Public Management; namely, study structure (flexibility and market-driven profiles), credits (standardization, mobility and effectiveness) and quality assurance (external control). In conclusion, the paper suggests that the $\mathrm{BP}$ primarily represents a problem in understanding a situation that displays signs of the radical transformation of the social function of one dimension of societal life higher education. Although it is clearly an adaptive reaction to the (neoliberal) transformation of society, it has also become part of the ideological games played by certain special-interest groups and, as such, we must make continual attempts to gain a deeper understanding of it.

Key words: Bologna Process, neoliberalism, management, higher education

It is widely known that in the past decade universities have been criticised as rigid and self-enclosed institutions. They allegedly fail to conform to the requirements of both the market and students themselves, and are managed in an obsolete and inefficient way [COM 2006; Com 2011; Opinion 2009]. Suggestions made by politicians and entrepreneurs favour the intro- 
duction of the so-called "New Public Management" (NPM) approach ${ }^{1}$. Yet, even fifteen years ago, Parker and Jarry were pointing out the risks inherent in this choice using the "McUniversity" metaphor [Parker, Jarry 1995]. They analysed in detail the "new management" practices in the public sector and discussed the "loss of confidence" in academic leadership, i.e. the tendency on the part of professionals at universities to promote business themes and "programmes" and to incorporate management and evaluation methods from the business sector into the world of academia. Of the number of tools used in the so-called modernization of universities and their management in Europe, the Bologna process is of paramount importance.

In the Czech Republic, as well as in other central European countries, this process is usually conceived from the perspective of political and economic "transition" from communism to a market oriented democratic society, from an elite to a mass higher education system [Tomusk et al. 2007]. Consequently, in the Czech academic milieu, the Bologna Process agenda has been insufficiently analysed; it has been accepted as a self-evident political task [Šima 2011]. The purpose of this article is to demonstrate the need to see the phenomenon from a wider perspective.

There is probably no phenomenon in educational policy that has been more inconsistently evaluated than the Bologna Process and the entire reform agenda associated with it. On the one hand, the evaluation documents of the EUA and authors close to the European Commission present a clearly positive point of view, where, at most, they criticise the slow pace of the reforms, their selectivity and lack of completeness, and certain unexpected effects. However, they never question the necessity of the reforms [Reichert, Tauch 2003; 2005; Stocktaking Reports of the Bologna Reform Process, 2005; 2007; Reichert, 2010]. At the other end of the spectrum, the Bologna Process is seen as a direct symbol of the "emptiness of the European Higher Education Area" and leads to comments such as "the misery of European Universities has a name: Bologna" [Liessmann 2008: 73]; while some talk of "Bologna's blind alley" [Eurozine 2010]. Nevertheless, the tendency to brush off critical voices aimed at the Bologna Process by referring

1 Since the 1980s, the dominant trend in public policy has been to advocate the application of private-sector management models to the public sector. The "new public management" model, part of this managerial trend, focuses on increased cost-efficiency and organizational flexibility. For public higher education, its implementation has meant less reliance on state and public funding and more dependence on private financing. It favours well-paid "expert" entrepreneurial bureaucrats as university administrators instead of academic leaders. "The buzz words of NPM are efficiency, effectiveness, delivery, flexibility, measurement, and outputs. Noticeably absent from this list are the normative ideals of equality, common good, and justice" [O'Halloran cited in Besosa 2007]. 
to an eccentric philosopher hopelessly dreaming about the failed Humboldtian ideal runs into at least two major difficulties. The first is the chain of long-running mass protests against the reforms associated with the Bologna Process, which were organised in a number of European states between 2006 and 2010 by both students as well as staff. The second consists of the analyses and articles completed by many other experts (and not only philosophers), who all point out that the motives behind the Bologna Declaration [1999] take on primarily an economic power aspect [Charle 2007] and that the associated reforms are only one part of the global trend to commodify and privatise universities according to the pattern of the Chicago neo-liberal school [Slaughter, Leslie 1997; Delanty 2003; Lorenz 2007]. The main question that therefore remains is whether the Bologna Process is primarily one of the elements required for the necessary (and desirable) adaptation of universities to the new social conditions or whether it is a Trojan horse sent out to introduce neo-liberal changes into the field of higher education. ${ }^{2}$ In considering this subject, I will first address the circumstances surrounding the origins of the Bologna Declaration, I will then go on to investigate the declared objectives and, finally, to look at the actual consequences that can be firmly established ten years after the event. In conclusion I refer back to the Czech situation.

2 There is not enough room here to describe the forms, symptoms and impacts of neoliberalism in education (for more details see [Apple 2001]) and its relation to human capital theory [Becker 1994]. Briefly, as the neoliberal hegemony has increasingly shaped individuals' common sense, commodification, commercialization, and marketization, as well as the extension of market logic and the prioritization of economic outcomes have come to redefine the purpose and role of social, cultural, and political institutions including traditional universities and their culture [Apple 2001]. Human Capital Theory links the neoliberal credo with the specific field of education. It not only believes that human beings themselves are capital. In modern Human Capital Theory all human behaviour is based on the economic self-interest of individuals operating within freely competitive markets. Other forms of behaviour are excluded or treated as distortions of the model. And the overall economic performance of the country is increasingly more directly based upon individuals' knowledge stock and their learning capabilities [Fitzsimons 1997]. Obviously, the individuals are conceived of as a special kind of company. They have to become managers of their own lives, who should strive to sell themselves at the most favourable price. And through such a self-concept they should contribute to maximizing the profit of real companies and economies. The ideas of efficiency, excellence, flexibility, stock of (international) experiences and mobility are the key attributes to be learned at school and in universities; some relate this process called "capitalization of education" directly to the Bologna Process which "completes a fundamental transformation, one that has long been underway, in how education and employment is provided - and finally overcomes opposition to this transformation ..." [Münch 2010: 1]. The result of Bologna is an increasing stratification and hierarchisation of higher education institutions and their disintegration at the national level. 


\section{A Europe of knowledge or a Europe of banks?}

It is a well-known fact that the Bologna Declaration was more or less preceded by a previous incarnation in the form of the Sorbonne Declaration. It is, however, less well-known that the actual Sorbonne Declaration from 1998 was preceded by a study of the French higher education system commissioned by the French government that was just taking over the helm. Just for a moment let us remain at the anecdotal level and examine whether we cannot find some rationale. According to Charle [2007], in 1997 the then Minister of Education Claude Allègre entrusted a committee headed by the world-renowned economist Jacques Attali with the task of preparing an analysis of the entire French tertiary education system within the international context and proposing measures to increase its effectiveness [Attali et al. 1998]. The new government set forth the premise that the French economy was stagnating over the long term and was consistently less and less competitive. It sought to rectify the situation through improving the effectiveness of higher education in order to ensure that graduates were better prepared for the labour market and that talent was not wasted. The analysis focused on the highly complex, multilateral and impermeable system of university studies. This system comprises universities, to which access is guaranteed by law to every secondary school graduate, as well as the highly selective Grandes Écoles, and other institutions of higher education and higher vocational schools (University Institutes of Technology, or IUTs). Measures aimed at increasing movement in both directions (from university to the Grandes Écoles and vice versa) would, however, require studies to be broken down into smaller segments and harmonised in order for these transfers to be possible. The proposal to prepare a coordinated structured study programme also contains comparisons with American and British research universities, specifically with how they operate, and how they are financed and managed. These particular institutes of higher education are generally considered to be the most productive and make the greatest contribution to economic productivity. For this reason they were used as an example for the reforms under consideration for French universities.

Attali's report from April 1998 thus attempts to resolve what was originally a specifically French issue. Minister Allègre submitted a summarised version together with recommendations at the end of May 1998 as a topic for discussion at a meeting of four education ministers (from France, Great Britain, Germany, and Italy) that took place at the Sorbonne. All four were dissatisfied with the low degree of competitiveness of the European higher education systems and the fact that they were not very attractive - in particular for gifted Asian students. At first, the ministers opted to follow an externally formal procedure: to structure studies using the American format of 
3/5/8 (bachelor, master and doctoral studies), thus increasing internal permeability and simplifying student mobility. At the same time, they hoped to add an intellectual dimension to the European unification process: through exchanges and the sharing of common goals a contribution would be made towards solidifying common European cultural values. Last, but not least, higher education in Europe would be at the highest possible level and attractive the world over. The Sorbonne communiqué paved the way to the Bologna Declaration, which was signed one year later [Charle 2007].

The "extraordinary successes" of the Anglo-Saxon model of higher education offers a means through which the main objectives can be realised. Europe wants to find a successful resolution to its difficulties (whether imagined or actual) by simulating this system. ${ }^{3}$ Regardless of whether or not the Sorbonne Declaration is primarily motivated by concerns about Europe finding a place for itself on the global higher education market, it seems also to be an attempt to exert cultural influence throughout the world and to supplement the European unification process with an intellectual dimension. Nevertheless, the eight fundamental objectives for the harmonisation of the higher education system architecture in Europe that were adopted in Bologna in 1999 are already in the spirit of adding economic instrumentality [Keller 2008; Winkin 2008]. This latter aspect was announced without any further ado as a programme to be undertaken during the Lisbon Conference in 2000, which through its well-known "strategy of how to become the most dynamic and most competitive economic block in the world in the shortest time possible" ${ }^{4}$ significantly alters the original spirit of the Sorbonne Decla-

3 Chris Lorenz draws attention to the fact that the extraordinary success of the AngloSaxon model is primarily due to the extraordinary position that the English language holds at a global level and is not the result of the formal structure of educational institutions in the Anglo-Saxon world. However, this premise has never been seriously analysed and this particular question has never been raised at the regular political discussions that are held on the subject [Lorenz 2007: 38].

4 Short timeframes, haste, the search for easy solutions along the lines of: "education is the 'main link' in the production of innovations, which are the engine that drives the economic growth that provides the ultimate guarantee for increased profits and prosperity" are reminiscent of the slogans used by all regimes that are based more on ideological tenets than on reality ("Even this generation will see ...", "Catch up and overtake by the year xxxx"; all in all, the Leninist "main link" method is also present in the slogans promoting competitiveness through education). Bill Readings [1996] says that the new reference model of University of Excellence replacing the idea of the university based on the development of the culture of knowledge is "a corporation driven by market forces, and, as such, is more interested in profit margins than in thought". Readings urges us to imagine how to think, without concession to corporate excellence or recourse to romantic nostalgia within an institution in ruins. His appeal for a new community of thinkers contrasts with the competitiveness-oriented and instrumental imperatives of the neoliberal discourse. 
ration. From the intellectualisation of the European concept (so that Europe is not solely an economic zone of free trade and work force mobility), from highlighting its cultural and social dimension, higher education becomes subordinate specifically to those economic principles that were to be balanced out: a free market for higher education, competitiveness, accountability (from the accounting perspective) and efficiency as opposed to purposefulness (that is to say, the effectiveness of institutes of higher education is perceived in a very narrow manner only in the sense of costs and benefits as efficiency instead of being viewed according to the level and quality at which the purposes of the institutions are realised, i.e. as efficacity).

In reality, it is therefore possible to view the Bologna Declaration together with the Paris (Sorbonne) Declaration and the Lisbon Strategy as one consolidated whole. According to Lorenz, it is possibly even more important to consider what is not discussed in the documents or at the conferences. Specifically that the Bologna Process followed by the Lisbon Strategy contributed to promoting the economic reduction of education with the goal of making higher education a market commodity and viewing it according to its key functions - the delivery of a work force to the labour market and one of the factors for economic growth [Lorenz 2007: 40]. ${ }^{5}$

\section{What did the Bologna Declaration proclaim?}

As indicated previously, the Bologna Declaration lies somewhere between the intellectual and cultural dimensions emphasised in the Sorbonne Declaration and the hard-core (neo-liberal) economically focused programme set forth in the Lisbon Strategy. For this reason, the objectives of the Bologna

5 Lorenz draws attention to an interesting implication. Up until the mid-1980s, public services, such as healthcare, education, postal services and others, were not included in international trade agreements (as regulated by GATS). In 1986 the Uruguay Round of World Trade Organisation (WTO) negotiations was launched and ultimately led to the formulation of the GATS (General Agreement on Trade in Services), which was signed by all of the WTO members. However, even at the end of the 1990s, the provisions of the GATS were being fulfilled at a very slow pace, which led to unrest on the part of the traders involved in the education business as it was not possible to create the necessary market environment for this particular commodity [40-43]. A1though, at its most general level, the GATS binds its signatories to removing obstacles to trade, each country has the ability to independently decide which of the sectors will be gradually liberalised, the extent to which they will be liberalised and for how long. For a region such as Europe, it is that much more necessary to unify and standardise higher education - which still remains under the sponsorship of the member states. Only through reducing costs (by removing the excessive diversity of educational systems) will it be possible to attain a high level of competitive strength and return on investment. 
Process are, for the most part, formulated academically and it was not very difficult to obtain support for them from university rectors and their associations (see the Prague Communiqué from 2001). Divested of any deeper level of reflection and without any significant support based on empirical facts, which would indicate the existence of reasons for fundamental reforms, ${ }^{6}$ the majority of the formulated objectives appear to be technically neutral measures.

The following are the declared objectives (as set forth in the Bologna Declaration of 1999):

1. To establish a European Higher Education Area: This particular objective is not explained in the declaration and no details are specified as to why this area should be established or why the current situation does not make it possible to attain the goals that are expected of it. Nevertheless, in the summary statement Reichert draws attention to the positive effects attained through meeting this objective. According to her, it made it possible to mobilise university representatives and gradually involve them as active participants in the Bologna Agenda (they are no longer simply players who must come to terms with the commitments made by politicians). In addition, an area is created within which it is possible to combine "soft standards" (which take on the character of voluntarily accepted obligations as opposed to administrative orders) together with bottom-up agenda setting, thus creating an interesting arena for European educational policy whilst continuing to respect national viewpoints and specific national aspects. Furthermore, the common area established the potential for sharing analyses and best practices at a time when it was necessary to face a universalised approach to higher education [Reichert 2010: 103-105].

2. To increase the international competitive strength of this area: It is becoming apparent that this is the central idea of the entire Bologna Process. If we are to consider European educational policy as being at least minimally consistent, then the Lisbon Strategy, which is dominated by the rhetoric of neo-liberal economists emphasising the accountability of universities, provides confirmation of this statement and the orientation of education towards the labour market and innovation. Additional communiqués (in 2001, 2003 and 2005) added individual goals to the Bologna Agenda, such as curricular reform, a qualifications framework, the reform of doctoral studies, the theme of ensuring quality, etc. However,

6 The adoption of the Declaration, which is intended to transform the structure and function of higher education in an historically significant manner, without any sort of serious debate (i.e. long-term, in depth and held at a mass level) on the part of those who are most affected is shocking to the academic world. 
when compared to the ultimate target value, which is an increase in economic competitiveness, they are unambiguously instrumental in nature. If we formulate the main objective of the Bologna Process in this manner, then the individual technical, structural and management measures appear in quite a different light.

3. To create a comprehensible system of qualifications: Diplomas that are compatible and comparable will support the employment of European citizens in any and all of the EU member states. The concept of the free movement of individuals of course also requires the removal of all barriers, including the acknowledgement of education (diplomas). However, the free movement of individuals is then placed in a preferential position as a target value and it is necessary to reduce diversity, specificity, and the special individual aspects of each national, cultural and institutional context.

4. To implement a two-cycle degree structure: Specifically this would include the first (pre-graduate) stage of at least three years linked to the labour market and a second (post-graduate) stage that would be either a shorter term of master studies or a longer term for doctoral studies for those who have research ambitions. The educational structure is the objective of the Bologna Process that receives the most media attention and has practically become the pars pro toto - the first thing anyone ever thinks of and voices an opinion on in relation to the Bologna Declaration is the study structure. The other objectives - possibly with the exception of mobility - are considered more only at the level of educational policy experts. The declared purposes behind the structure have already been mentioned - specifically increased transparency and mobility during the course of studies, which is intended to lead to more effective and, on average, shorter studies. Within a system of study programmes, it will be easier for students to "find" themselves and not remain trapped in a "tunnel" of lengthy master studies. In addition, students will be able to take advantage of acknowledged diplomas received on the basis of individually shorter study cycles (than is currently the case) in order to obtain practical experience or work experience abroad.

5. To significantly increase the mobility of students, teachers, researchers, and administrative employees: This is an objective that seems to be entirely obvious and does not require any justification or discussion: obtaining experience abroad is always beneficial. We will not find any arguments either for or against mobility anywhere (not even at a later date). The primary reason why mobility remains necessary in a consistently more open information-linked world is not, however, clear - at what point during the course of studies is it important and to what extent? If we ask ourselves this question, we might be able to identify some internally con- 
flicting objectives within the overall agenda. For example, such things as pressure for the standardisation (if not ultimately the complete uniformity) of studies within the same field in all of the members states (see the credit system as defined in the sixth objective) or the detailed definition of outputs from education and a qualifications framework (see the seventh objective and other tasks involving curricular reform, which will make studies comparable at a basic level of knowledge and skills) may lead to mobility being cognitively useless for the majority of individuals. If everything is essentially the same everywhere, then there is no reason to abandon one's university, although expanding foreign language skills and knowledge of different cultures have their own significance [cf. Liessman's critique of the absolutisation of mobility, Liessman 2008]. Moreover, there are doubts about the dominance of study motives for the students' mobility. Based on a comparison of the ranking of the most attractive student mobility destinations with the most preferred tourist countries Keller documents the fact that Erasmus mobility could be driven more by "student tourism" than by the quality and pertinence of the specific teaching with which students are provided at universities abroad [Keller 2008].

6. To implement a common credit system (ECTS) as a resource for improving student mobility: If a credit system is justified solely as an instrument to facilitate mobility, then the requirement to provide thorough justification of its necessity is that much stronger. Credits do in fact make it easier to acknowledge the results of studies faster, more economically and more comprehensibly. This is, however, offset by yet another shift in the way the value of education is viewed. Thanks to the definition of a system based on "study load", credits take the utility value (what specifically the student has learned) out of the method used for evaluating studies and stress the exchange value (how much time was dedicated to studies). Each credit is defined by the number of hours spent on learning the specific knowledge and skills and includes direct as well as indirect learning time and the additional preparation time spent by a student. In this way, it is possible to compare education anywhere in the world; however, the validity of this comparison is very low and, in fact, conceals a certain tautology as expressed in the statement "everywhere people study, studies take place" [Liessmann 2008: 77]. This unilateral conversion function of credits, as reflected in the modified view of a university education, emphasises even more the fact that an education can be attained even outside the academic sphere [Lorenz 2007: 36].

7. To improve the quality of the education provided by European universities and to ensure their verification with the assistance of international (Euro- 
pean) common criteria and methods using international external indicators and procedures (quality assurance): Another significant shift in the academic world is linked with the generally accepted goal of "being even better". It is founded objectively on the concept of common quality standards that are externally determined and subsequently "guaranteed", that is to say implemented, developed and maintained. The final result is the notion that universities will be provided with tools that they can use to consistently improve and will voluntarily assess the quality of all their activities on an on-going basis, preferably by using the services of external evaluation agencies. Extraordinary emphasis has been placed on these activities since 2005. Both accountability (reporting, primarily in the financial sense of the word) and external quality control have been the subject of discussions [CHEPS et al. 2007]. Debates and resistance on the part of the academic community were to be expected. It was never properly explained why it is suddenly of utmost importance to ensure the quality of universities externally with the assistance of new standards and procedures and why the professional academic control mechanisms that have been in place and performed by academic staff for centuries are no longer sufficient. It is not clear when and to what extent the existing system failed. Many strongly believe that the concerns about the quality of European institutions of higher learning conceal efforts to replace the autonomous professional decision-making and quality criteria in place for the management of universities with managerial methods taken from the business sector, which were already underway even prior to the Bologna Declaration ${ }^{7}$.

8. To strengthen the European dimension in all areas: This includes research, mobility and other forms of interuniversity cooperation. The text does not, however, define exactly what the "European dimension" means.

Within the original declaration, it is difficult to separate the objectives from the instruments. It is also not possible to clearly determine which instruments are to be used for specific objectives and how they will contribute

7 In relation to this fact, it is necessary to draw attention to the anticipatory writing of Parker and Jarry on the "McUniversity" metaphor mentioned above [Parker, Jarry 1995]. Delanty [2003] also specifies the efforts of neo-liberals to allegedly improve the management of universities by using managerial methods as one of the several "cultural contradictions" that can be seen in the changes that have been launched. The most ironic aspect of the entire issue is probably the fact that the reformers do not apply another NPM tool to themselves, specifically "evidence-based policy" - the proposed measures for external quality control are not based on any empirically proven facts about the failure of the academic management model. 
towards realising the objective. However, the original mission can be determined and reconstructed.

For the future enlarged Europe, politicians have defined the key task for the coming decade as being aimed at increasing the competitive strength of the European economy. This economy is being significantly transformed into a service and knowledge-based economy, the development of which is founded primarily in technological innovation, which is in turn the result of new knowledge. For this reason, it is necessary to manage the higher education sector more efficiently, that is centrally, which, up to now, has been governed by the political decisions of the individual member states, and to integrate this sector (establish a common area). Furthermore, it is necessary to improve the sector's effectiveness through the implementation of new rules that are supposed to have already been functioning successfully in the business sector for a number of years, specifically to standardise the structure (the study structure), to bring to the table the same standards for activities (quality assurance) and the same mechanisms for managing and controlling institutions. This is not something that can be completed on the basis of a single task - the process must be on-going. (According to Lorenz "in Bologna the EU knowingly adopted a decision to regularly supervise and reform the European higher education systems" [Lorenc 2007: 37]).

\section{What are the results?}

The final analytical reports published by the EUA (Trends) state that there are great differences with regard to the implementation of the individual objectives set forth in the Bologna Declaration, both at the level of the individual member states as well as at the level of various institutions of higher learning in each state. They agree that attention is essentially focused on three pillars of the Bologna Agenda: the study structure, credits and quality assurance. Crosier et al. [2007] claim that, out of a representative sample of approximately one thousand European institutions of higher learning, 83 per cent have structured their study programmes and that it is expected that in 2010 the vast majority of students will enrol in these programmes. In addition, a relatively satisfactory level of comprehensibility and comparability of diplomas was attained through the use of credits and supplements to diplomas. The establishment of ENQA - the European Association for Quality Assurance in Higher Education - as a network linking agencies responsible for evaluating the quality of institutions of higher education is also viewed as a success. Some consider the activities taking place in this particular area to be the most dynamically developing within the entire Bologna Process [Reichert 2010]. Others warn that a certain risk lies in the possible 
increase in the methods of assessment that are used. It has been mentioned that universities will be caught up in a web of never-ending reports, records, internal evaluations and audits, which runs the risk that the energy and resources that would otherwise be dedicated to teaching and research will be used elsewhere, thus dramatically transforming academic culture ([Delanty 2003], according to whom this negative transformation has already occurred).

However, Reichert, in her analysis [2010], differentiates between the planned results, the objectives that have not been realised and unplanned effects. Her list of planned and attained results includes the creation of a new common platform for formulating European policy for higher education, the structuring of studies, the developments in mobility, and two particularly dynamic areas: specifically, the reforms to doctoral studies and externally performed quality assurance (the definition of standards and methodological procedures and rules for the accreditation of evaluation agencies). Her overall assessment is, however, very cautious, up to the point of being critical.

In her opinion, the results are more of a disappointment than anything else and progress is slow. For example, the structuring of studies and the evaluation of study load using credits were more or less only formally implemented. The net result is that students are overloaded during their bachelor study programme, which was created by mechanically "halving" the original master studies programmes. The efforts to shift as many subjects as possible into the bachelor studies programmes in order to ensure that the studies are as complete as possible according to the original concepts, leads to discontent on the part of the students. Likewise, credits calculated mechanically without any logical foundation have only very little reporting value: a course is assigned a certain number of credits where the number of hours of contact teaching are used as a base and then multiplied as required in order to ensure that, proportion wise, they correspond to the total number of credits allocated to a semester. The actual study load of the student is ignored and, in particular, no consideration is given to the contribution that the course (or subject) in question makes to the clearly defined outputs of the study programme [Reichert 2010: 108].

This brings us to the main criticism associated with unrealised objectives. According to Reichert, it was not possible to institute a shift towards student-centred education and the desirable curricular reforms were not implemented. In particular, this concerns the "delay" in determining what the outputs from the study programmes should be and defining a qualifications framework according to labour market requirements. In addition, she also believes that it is still rare to see education focused on the graduate's abili- 
ties. In other words, quality assurance is still being slowed down as a result of the absence of curricular changes. The primary fault lies in the unwillingness of the nation states to invest any resources in these changes as well as in the resistance that exists on the part of the academic sector - although there are indications of a slight change in the attitude of the academicians. The universities in north-western Europe have been the most obliging, but the situation is changing in Europe's other regions as well. This is evident in, amongst other things, the significant increase in the quantity and quality of advisory and consultancy services, the attention paid to student needs, the mechanisms of internal quality control used, and the willingness to communicate with employers [Reichert 2010: 107- 109].

The unplanned effects are quite remarkable. Crosier et al. [2007], CHEPS et al. [2007], and Reichert [2010] all state that the Bologna Declaration played a special role as the catalyst for other reforms in the higher education sector. More specifically, the Bologna Agenda was often used (misused?) as an argument in favour of more in-depth national reforms. Most notably, these include:

- The need to create a new image for higher education overall, including newly defined profiles for the individual institutions and, in particular, a solution to the issues associated with professional training and its relationship to other forms of higher education (the diversification of institutions), especially in relation to the massification of tertiary education.

- The increased centralisation of the management of institutions of higher education and a change in the academic management style (greater autonomy for universities, increased pressure to perform self-evaluations and reporting, the need to formulate strategic priorities for the institution as a whole, and others).

- The increased influence of external players (employers, practitioners and representatives from cultural and civic organisations), not only in areas where this influence already existed (such as professional pedagogy, economics, management, engineering and medicine), but also through the creation of new management structures in other fields and types of institutions. Austria, the Netherlands, Denmark, Norway, Spain and several of the states of the Federal Republic of Germany are all mentioned as examples where external players have been included successfully.

Nevertheless, even the critical assessment of the Bologna Declaration does not deter the aforementioned authors from their convictions that reform (in the form in which it has been launched) is a priority - that it is necessary and positive. The criticisms do not go down to the roots and are not founded on alternative interpretations (the pressures exerted by the Lisbon Treaty for innovation are primarily interpreted as support for improving the qual- 
ity of higher education thanks to the viewpoints of "external stakeholders", which will increase the competitiveness of the educational institutions, the member states and Europe as a whole, and are not viewed as a reason for formulating a hypothesis on the commodification and open privatisation of education).

The Czech situation is not entirely clear-cut. It is characterised by a lower level of resistance on the part of institutions of higher education than is the case in France, Greece, Austria, and Germany, where awareness of the interrelationships of the whole is much deeper. No discussions have taken place in the Czech Republic as far as viewing the risks to the autonomy of universities as a reason for weakening the state's responsibility for higher education. Likewise no debates have been initiated as to whether the state can manipulate existing autonomy in a manner whereby pressure will be exerted to create a survival strategy voluntarily and "spontaneously" using private financing, including the "obvious" requirement to introduce tuition fees. Nor has any analysis been performed with regard to the relationship between external evaluations of quality and the required management structure that is more influenced by external players.

On the other hand, the developments to date are comparable to the situation in the majority of the EU member states [Eurostat 2009]. It is characterised by the successful, albeit formal, structuring of studies and a notable increase in mobility, primarily on the part of students. The implementation method was not at all "soft" as implied by Reichert. To the contrary, it was simply performed and incorporated in the applicable legislation without any in-depth discussions or further justification (since 2004 "a master studies programme is the continuation of the bachelor study programme, unless the specific nature of the studies requires otherwise"). Thus far it also seems that the expectation that the restructuring will create better decision-making conditions for students with regard to their path of study, consequently leading to a decrease in the average length of their studies, will not be realised.

Insufficient harmonisation within the tertiary education sector is not solely a Czech issue - as of this point, quality evaluation tools have not been used at all to resolve this critical issue. It is still not known how a bachelor degree will be utilised or how to deal with the extremely high number of individuals striving to obtain a university degree at this time. The position of professional vocational schools and a short timeframe to obtain professional training, which should have been resolved with the assistance of the recommendations made by the Bologna Declaration, have become even more unclear. After ten years, all the development that has occurred in this area comes across as an unrestrained and unmanaged process, which has 
been selectively inspired by the objectives set forth in the Bologna Declaration without knowingly applying the concepts contained in the Declaration and without any awareness of the impact its implementation might have. After all, even the main conceptual materials prepared on the basis of a recent centralised decision - specifically the White Paper on Tertiary Education [2008] - do not especially take the objectives of the Bologna Process into account.

\section{Conclusion}

It is becoming apparent that the most burning issue associated with the development of tertiary education in Czech Republic is that there is not enough critical reflection in the development of universities and other institutions of higher learning in general and that there is a lack of research coverage for this particular area [Kohoutek 2011]. This concerns not only the absence of research in the form of statistics and empirical studies showing the development of individual indicators (their "performance"). As much as descriptive data is an essential prerequisite for any sort of serious contemplation, the difficulty lies elsewhere. We can assign various levels of significance to numeric data, such as the number of structured study programmes, the number of incoming and outgoing students, the number of joint-degree programmes and cotutelle agreements, the implementation of a standard level of quality, etc., according to the overall interpretative framework.

However, it is not possible to ignore the broader context of social, economic and political changes: the imperative streamlining on the part of the states and the requirement to decrease public expenditure, which are presented as almost a natural necessity in all areas that have thus far been only minimally impacted by profit-making ideology (healthcare, security, education), bring the certainty of economisation expressed in the normative nature of the instrumental concept of education as a tool for economic use and the personal investment of an individual (and no longer as an individual's right to personal development that is also beneficial to society as a whole), and the commodification of education with the need to create the appropriate market conditions for its conversion and the valuation of educational investments. As far as this particular context is concerned, the Bologna Process is becoming the target of undeserved attacks and has been called an act that has led to certain accompanying negative phenomena (a decrease in the quality of higher education, massification, extended duration of study, a focus on pragmatic market-related, essentially non-academic study programmes, see [Liessmann 2008] or [Schultheis 2008]). It is likely that such trends in socioeconomic development, which we may describe 
as marketization of higher education, and an insistence on the conception of the university as a direct agent in economic growth and in competitiveness would have had an effect, the Bologna Process notwithstanding [Blomert, Meyer-Renschhausen 2009]. On the other hand, certain positive aspects that are associated with the Bologna Process might have come about even without it (such as increased mobility and pressure to establish more practical, shorter higher education programmes).

Of course according to the subsidiarity principle in the area of education, the interpretation and binding nature of the objectives of the Bologna Process are entirely within the jurisdiction of the member states, which have used the opportunity in order to make budget cuts for higher education or to push through legislative amendments [Tomusk et al. 2007; Reichert 2010]. Nonetheless, it becomes necessary to ask: why is it that the Bologna Process and its objectives could be misused to such purposes so easily?

The Bologna Process therefore primarily represents a problem in understanding a situation that displays signs of the radical transformation of the social function of one dimension of societal life - higher education. Although it is obviously an adaptive reaction to the transformation of society, it has also become part of the ideological games played by certain special-interest groups and, as such, we must make continual attempts to gain a deeper understanding of it.

\section{References}

Apple, Michael W. 2001. Educating the 'Right' Way: Markets, Standards, God, and Inequality. New York: Routledge.

Attali, J. Et Al. 1998. Pour un modèle Européen d'enseignement supérieur. [online], December 2011 <http:/ / guilde.jeunes-chercheurs.org/reflexions / documents / 1998attali.pdf>

Becker. G. 1994. Human Capital: A Theoretical and Empirical Analysis With Special Reference To Education. Chicago: The University of Chicago Press.

Besosa, M. 2007. New Public Management. In Academe [online], May-June 2007 <http://www.aaup.org/aaup/pubsres/academe/2007/mj/feat/beso1.htm>

Blomert, R., Meyer-Renschhausen, E. 2009. Kann man die Aufklärung kommerzialisieren? Die Hintergründe der neuen Rahmenbedingungen für die Universitäten. In Kellermann, P., Boni, M., Meyer-Renschhausen, E. (eds.). Zur Kritik europäischer Hochschulpolitik. Forschung und Lehre unter Kuratel betrienswirtschaftlicher Denkmuster. Wiesbaden: VS Verlag, 27-45.

The Bologna Declaration of 19 June 1999. Joint Declaration of European Ministers of Education“. [online] <https://bologna-berlin2003.de/pdf/bologna_declaration.pdf>

COM. 2006. (33) Final. Implementing the Community Lisbon Programme: Fostering Entrepreneurial Mindsets through Education and Learning”. In Communication from the EC [online] <http:/ /www.ec.europa.eu> 
COM. 2011. (567) Final. Supporting Growth and Jobs - An Agenda for the Modernisation of Europe's Higher Education Systems. In Communication from the EC [online] <http:/ / eur-lex.europa.eu/lexuriserv/lexuriserv.do?uri=com:2011:0567:fin:en:pdf> Crosier, D., Purser, L., Smidt, H. 2007. Trends V-Universities Shaping the European Higher Education Area. European University Association: Brussels.

Charle, Ch. 2007. Universités Françaises et universités Européennes face au défi de Bologne. In Charle, Ch., Soulié, Ch. (eds.). Les ravages de la "modernisation " universitaire en Europe. Paris: Éditions Syllepse, 9-32.

Cheps et al. 2007. The Extent and Impact of Higher Education Governance Reform Across Europe. Final Report to the Directorate-General for Education and Culture of the European Commission. Brusseles: European Commission.

Delanty, G. 2003. Ideologies of the Knowledge Society and the Cultural Contradictions of Higher Education. In Policy Futures in Education, 1(1): 71-82.

Eurostat. 2009. Social Dimension and Mobility in the Bologna Process [online] <http:/ / epp.eurostat.ec.europa.eu>

Eurozine Editoval. 2010. Bologna's Blind Alley. In Eurozine [online] < http://www. eurozine.com/articles/2010-07-01-editorial-en.html>

Fitzsimons, P. 1997. Human Capital Theory and Participation in Tertiary Education. In Mathews, K-M., M. Olssen (eds.). Critical Perspectives on Education Policy for the 1990s and beyond Palmerston North: The Dunmore Press. 107-129.

Garcia, S. 2007. L'Europe du savoir contre 1'Europe des banques? La construction de l'espace Européen de l'enseignement supérieur. In Actes de la recherche en sciences sociales (Constructions Européennes), 80-93.

Keller, F. 2008. Nomaden des wissenschaftlichen Feldes. Über die neue Geometrie des Wissens und die Kunst des Navigierens. In Schultheis, F. (ed.). Humboldts Albtraum. Der Bologna-Prozess und seine Folgen. Konstanz: UVK, Verlagsgesselschaft, 47-62.

Kohoutek, J. 2011. Long Night's Journey into Day: Implementation of Czech Policy on Higher Education Quality Assurance. Prague. Doctoral Thesis. Charles University in Prague, Faculty of Social Sciences, Institute of Sociological Studies.

Liessmann, K. 2008. Teorie nevzdèlanosti. Omyly společnosti vědění (translated from the original german "Theorie der Unbildung: die Irrtümer der Wissensgesellschaft" "The Theory of Miseducation: The Failures of the Information Age"). Prague: Academia.

Lorenz. Ch. 2007. L'Économie de la connaissance", le nouveau management public et les politiques de 1'enseignement supérieur dans l'union Européenne. In Charle, Ch., Soulié, Ch. (eds.): Les ravages de la "modernisation " universitaire en Europe. Paris: Éditions syllepse, 33-52.

Münch, R. 2010. Bologna, or the Capitalization of Education. In Eurozine. [online] <http:/ /www.eurozine.com/articles/2010-07-01-munch-en.html>

Olssen, M. Peters, M.A. 2005. Neoliberalism, Higher Education and the Knowledge Economy: From the Free Market to Knowledge Capitalism. In Journal of Education Policy, 20 (3): 313-345. 
Opinion of the EESC On "Universities for Europe". 2009. ECO/LSO/256 CESE1719/2009, Art. 1.1. [online] <http://www.eesc.europa.eu>

Parker, M., Jarry, D. 1995. The Mcuniversity: Organization, Management and Academic Subjectivity. In Organization, (2): 319-338.

Readings, B. 1996. The University in Ruins. Cambridge: Harvard University Press.

Reichert, S., Tauch, C. 2003. Trends III: Progress Toward the European Higher Education Area. European University Association: Brussels.

Reichert, S., Tauch, C. 2005. Trends IV: European Universities Implementing Bologna. European University Association: Brussels.

Reichert, S. 2010. The Intended and Unintended Effects of the Bologna Reforms. In Higher Education Management and Policy. 22 (1): 99-118.

Schultheis, F. (Ed.). 2008. Humboldts Albtraum. Der Bologna-Prozess und seine Folgen. Konstanz: UVK, Verlagsgesselschaft.

Slaughter, S., Leslie, L. 1997. Academic Capitalism: Politics, Policies and the Entrepreneurial University. Baltimore: Johns Hopkins University Press.

Stocktaking Reports of the Bologna Reform Process 2005. [online], December 2011 <http://www.ond.vlaanderen.be/hogeronderwijs/bologna/documents / nationalreports2005.htm>

Stocktaking reports of the Bologna Reform process 2007. [online], december 2011 <http:/ / www.ond.vlaanderen.be/hogeronderwijs/bologna/actionlines/stocktaking. htm>

Šima. K. 2011. Editorial. In AULA, 19 (1): 4.

Tomusk, V. (Ed.). 2007. Creating the European Area of Higher Education. Voices From the Periphery. Dordrecht: Springer.

Winkin, Y. 2008. Der Geist Von Bologna: "Wenn Die Universitäten sich nicht Anpassen, wird es auch ohne sie gehen" In Schultheis, F. (Ed.). Humboldts Albtraum. Der Bologna-Prozess und seine Folgen. Konstanz: UVK, Verlagsgesselschaft, 183-186.

\section{Author:}

Stanislav Štech, Ph.D., Professor

Charles University in Prague

Faculty of Education

Psychology Department

M. D. Rettigové 4

11639 Praha 1

Czech Republic

Email: stanislav.stech@pedf.cuni.cz 